\title{
Soldiers, Martyrs, and Criminals: Utilitarian Theory and the Problem of Crime Control
}

\author{
Louis Michael Seidman $†$
}

If I were having a philosophical talk with a man I was going to have hanged (or electrocuted) I should say, I don't doubt that your act was inevitable for you but to make it more avoidable by others we propose to sacrifice you to the common good. You may regard yourself as a soldier dying for your country if you like. But the law must keep its promises.

-Oliver Wendell Holmes ${ }^{1}$

I only regret that I have but one life to lose for my country.

-Words attributed to Nathan Hale shortly

before his execution by the British ${ }^{2}$

Utilitarians who think about criminal justice issues have a problem. They must explain why it is that we have more crime than we want.

The law and economics literature on criminal $\mathrm{law}^{3}$ is laced with statements like the following: "Presumably, we could have as little crime as we wanted if we were willing to spend enough on police, courts, jails, and so on to make probabilities of arrest very, very high for most crimes."4 But one might fairly ask, if we could, why don't we?

$\dagger$ Professor of Law, Georgetown University Law Center.

I would like to thank Lonnie Athens, Richard Brandt, Stephen Cohen, Deirdre Golash, Steven Goldberg, Steven Salop, Warren Schwartz, Girardeau Spann, Mark Tushnet, Silas Wasserstrom, and Nicholas White for reading and commenting upon earlier drafts of this Article.

This Article could not have been written without the tireless research assistance of Andrew Luger and Mary Morton.

1. 1 Holmes-Laski Letters 806 (M. Howe ed. 1953).

2. H. Johnston, Nathan Hale 129 (1914).

3. Strictly speaking, there may be some distinctions between economic and utilitarian analyses of law, see Posner, Utilitarianism, Economics, and Legal Theory, 8 J. LEGAL STUD. 103 (1979), although the association between the two traditions is clear enough, especially in criminal law. See $\mathrm{R}$. Posner, Economic Analysis of Law 357 (1st ed. 1973). In this essay, I will use "law and economics" and "utilitarianism" loosely and more or less interchangeably to refer to consequentialist theories of criminal justice that attempt to justify punishment as a means of avoiding a worse outcome if punishment were foregone. Cf. $R$. WASserstrom, Philosophy and Social Issues $112-13$ \& n.3 (1980) (some historical elements of utilitarianism not essential to discussion of punishment; thus "consequentialism" is a better generic term).

4. Rubin, The Economics of Crime, 28 AtLanta Econ. Rev. 38, 41 (1978). For another representative example, see Stigler, The Optimum Enforcement of Laws, 78 J. Pol. Econ. 526, 527 (1970) 
Of course, a utilitarian utopia would not be crime-free. A central tenet of the utilitarian theory of crime control is that resources should be devoted to crime prevention only up to the point at which the marginal cost of prevention equals the marginal cost of the crime prevented. Nictims of criminal violence would remain, but these victims could take solace from the knowledge that their victimization was "efficient"-that, in other words, society as a whole would be worse off if we had taken the measures necessary to prevent them from being mugged in dark alleys.

I suppose that utilitarians of a Panglossian bent are prepared to defend the view that the present level of crime is optimal in this sense. If it were not, the argument goes, we would incur the additional costs necessary to make it so. If one truly believes that we can have as little crime as we want, it follows that we want as much crime as we have.

This tautology provides an answer of sorts to our question. But it is an answer that ignores an obvious reality: Many Americans are dissatisfied with the level of crime and would gladly pay in the currency of harsher sentences for more peace in our streets. ${ }^{5}$ Moreover, someone giving this answer thereby sacrifices any claim that we should pay attention to his analysis as a tool for social criticism. If the status quo is necessarily utility maximizing (because if it were not, we would change it), then this utilitarian cannot consistently argue for changing any state of affairs that presently exists.

Utilitarians can escape the charge of irrelevance by taking the opposite tack. They can insist that they are advancing a prescriptive rather than a descriptive theory, and that we should pay attention to their theory precisely because it is a tool for social criticism. ${ }^{6}$ On this view, the reason we

("The extent of enforcement of laws depends upon the amount of resources devoted to the task. . . . We could make certain that crime does not pay by paying enough to apprehend most criminals.").

5. One recent public opinion poll, for example, shows that $83 \%$ of those asked thought that the penalties for crime were not harsh enough. See T. Flanagan, D. Van Alstyne \& M. GotTfredSON, SourCe BooK of Criminal. Justice STATISTICs-1981, at 204 (1982). For a (now somewhat dated) discussion of the way in which political institutions have responded to this pressure, see $\mathrm{J}$. Wilson, Thinking About Grime 64-77 (1975).

6. Some advocates of economic analysis of law have become rather confused about this point. It has been argued that, as a positive matter, there is a "tendency of the set of all legal rules to become dominated by rules achieving efficient as opposed to inefficient allocative effects" and that this tendency will prevail "regardless of the attitudes of individual judges toward efficiency, the ability of judges to distinguish efficient from inefficient outcomes, or the interest or uninterest of litigants in the allocative effects of the rules." Priest, The Common Law Process and the Selection of Efficient Rules, 6 J. Legal Stud. 65, 65 (1977). See also Rubin, Why Is the Common Law Efficient?, 6 J. Legal STUD. 51 (1977) (arguing that efficient rules result from utility-maximizing decisions of disputants). Yet defenders of economic analysis also claim that their method has normative power-that it provides "a source of criticism and reform as well as understanding." R. POSNER, ECONOMIc ANALYSIS of LAw 17 (2d ed. 1977). See generally Posner, supra note 3, at 107-10 (economic theory of "wealth maximization" both positive and normative). It is self-evident that both claims cannot be fully correct. If economics is a system for describing what inevitably is, then it must give up its claim to guide us to what ought to be. 
have too much crime is quite simple: The people who formulate our crime control strategy are either not utilitarians or are inept at performing utilitarian calculations. If they could only be persuaded to abandon their misguided views and to implement a utilitarian program, we could quickly achieve a socially desirable outcome.

By foresaking the claim that their theory is descriptive, utilitarians save themselves from the charge that they are advancing no more than a tautology. But this move creates a new problem-one that is the subject of this Article. As moral theoreticians, utilitarians fully discharge their responsibility by telling us what we ought to do about crime. But the rest of us, who are interested in empirical outcomes as well as in normative theory, are entitled to wonder why, as a positive matter, society has not adopted the utilitarian theory of crime control. Perhaps, given enough time and enough effort, people will come around. But it is also possible that there are insuperable barriers to the adoption of certain utilitarian recommendations-that what some utilitarians tell us ought to be done cannot be done. If such barriers exist, then at least some forms of utilitarianism fail not only descriptively, but prescriptively as well. For utilitarians might then just as well rail against death and illness or earnestly urge repeal of the laws of thermodynamics.

Such barriers to implementation of certain utilitarian theories of crime control do exist. ${ }^{7}$ Specifically, our inability to control our feelings of anger and the blame we inflict on criminals prevents us from adopting a utilitymaximizing solution to the problem of crime. This inability, in turn, stems from the contradictory functions that blaming serves in our criminal justice system. On the one hand, blaming serves a preventive function. It reduces the total amount of crime in a manner that minimizes the social cost of crime control. On the other hand, blaming also serves a distributive function. It announces our choice of the group that will bear the social cost of crime and provides the rhetoric that justifies that choice. These functions conflict. While the preventive function of moral condemnation is indispensable to a utility-maximizing system of crime prevention, the distributive choice of the groups to be blamed will inevitably fail to maximize utility.

The remainder of this Article attempts to demonstrate the validity of these conclusions and to work through some of the dispiriting implications that they hold for us. My strategy is to begin by examining a highly sim-

7. Of course, in its weakest form, a utilitarian prescription is never subject to this attack. To the extent that utilitarians confine themselves to urging that we do the best that is possible under the circumstances, we can always follow their advice. I want to attack the more ambitious and interesting claim that it is possible to manipulate punishment and enforcement levels so as to reduce the social cost of crime and crime prevention to some theoretical minimum. 
plified version of act utilitarianism ${ }^{8}$ that assigns punishment levels to each individual in a fashion calculated to minimize the total social cost of crime and crime prevention. I argue that the self-conscious effort to assign punishment in individual cases so as to maximize utility produces clearly suboptimal outcomes. Moreover, so long as we insist upon pursuit of this effort, the model cannot be saved simply by adding complexity and qualifications to it.

Part II then sets out reasons why a more sophisticated utilitarian would wish to rely upon a rule that would forego punishment in individual cases even when such punishment would appear to maximize utility. Minimizing the overall cost of crime requires utilitarians to adopt a general rule that proportions punishment to perceptions of moral culpability. ${ }^{9}$

If such perceptions served only to reduce the total cost of crime, we could create an efficient system that incorporated them. But the act of

8. This is not the place for an extended discussion of the distinctions between act and rule utilitarianism. By "act utilitarianism," I mean an ethical theory that permits performance of an act if, but only if, the total expected utility for everyone affected by it is at least as great as that from any alternative act open to the agent. See R. BRANDT, A TheORY OF THE GoOD AND THE Righr 271 (1979). I mean to contrast this theory with a "rule utilitarian" approach that permits performance of an act if, but only if, it is not proscribed by a moral code the currency of which would produce at least as high an expected utility as the currency of any other moral code. See Brandt, A Utilitarian Theory of Excuses, 78 PHIL. REv. 337, 346 (1969). There is a vast literature concerning whether a distinction can be maintained between these two views, or whether one necessarily collapses into the other. See, e.g., D. Lyons, ForMs AND LimTrs of UTILITARIANISM 62-118 (1965) (rule utilitarianism and act utilitarianism extensionally equivalent); D. REgan, UTII.TTARIANISM AND Co-OPERATION 95-103 (1980) (sophisticated forms of rule utilitarianism collapse into act utilitarianism); Smart, An Outline of a System of Utilitarian Ethics, in J. SMart \& B. WILLIAMS, UTILITARIANISM For aNd Against 3, 9-12 (1973) (an adequate rule utilitarianism necessarily collapses into one-rule system identical with act utilitarianism).

There is also a controversy concerning which value utilitarians should strive to maximize-compare, e.g., R. BRANDT, supra, at 246-53 (happiness) with R. SARTORIUS, INDIVIdUAL Conduct and Social Norms 27 (1975) (desire satisfaction). See generally Elster, Sour Grapes-Utilitarianism and the Genesis of Wants, in UTILITARIANISM AND BEYond 219-38 (A. Sen \& B. Williams eds. 1982) (theories of desire satisfaction fail to distinguish autonomous from nonautonomous desires). On the possibility of making interpersonal utility comparisons, see, e.g., R. BRANDT, supra, at 257-65 (inductive inference and motivational theory of pleasure provide grounds for making interpersonal utility comparisons); Goldstick, Assessing Utilities, 80 MIND 531 (1971) (interpersonal utility comparisons possible when desire measured by sacrifice of negotiable entity). Rule utilitarians are themselves divided between those who believe that one should measure the utility of the mere promulgation of the rule in question and those who would insist on actual conformance to the rule. See R. BRANDT, supra, at 188-93. For the most part, the arguments presented here do not require me to take a position on these questions.

9. This argument is no more than an example of the more general proposition, often advanced by rule utilitarians, that a case-by-case assessment of the utility of individual acts undermines our ability to mold people's expectations and incentives in a utility-maximizing fashion. See, e.g., R. BRANDr, supra note 8, at 274-76 (case-by-case assessment too difficult and time-consuming and likely to lead to self-interested rationalization); Harsanyi, Morality and the Theory of Rational Behavior, in UTILTARIANISM AND BEYOND 39, 58-60 (A. Sen. \& B. Williams eds. 1982) (spread of act utilitarianism would lead to insecurity). For an application of this argument, somewhat different from my own, demonstrating that act utilitarianism would undermine the deterrent force of the triminal law, see $D$. Hodgson, Consequences of Utilitarianism: A Study in Normative Ethics and Legal. TheORY 91-99 (1967). But see D. REGAN, supra note 8, at 66-82 (arguing that act utilitarianism can alter expectations of potential offenders). 
blaming serves not only to minimize the total social cost of crime, but also to justify the way in which that cost is distributed. Part III analyzes this distributive function and attempts to demonstrate that there is a natural tendency toward a distribution that fails to minimize total costs.

Finally, Part IV further explores the problems created when the preventive and distributive functions of blaming conflict. I argue that inefficiencies in the distribution of the cost of crime inevitably interfere with the effective communication of blame, and thus limit the effectiveness of blaming as a tool for crime prevention. Consequently, it is impossible under utilitarian analysis to achieve the low level of crime that society currently desires. I also identify a threat lurking behind the current system-that if criminals ever reject the legitimacy of blame, they will come to see themselves as soldiers or martyrs, and a cycle of escalating violence will ensue.

So as to avoid misunderstanding, I wish to make one additional point at the outset. It would be a mistake to read this Article as an attack on utilitarianism as a normative justification for punishment. On the contrary, the burden of proof should be placed upon those who advocate punishment that is simply the gratuitous infliction of additional suffering. Indeed, one could read this essay as no more than an attempt to work through the complex implications that sophisticated utilitarianism holds for the criminal justice system. My preference, however, would be to avoid normative discourse altogether, since such discourse implies that there are meaningful choices to be made. Our crime problem is tragic precisely because we have so little room to maneuver. Our unhappiness about crime stems from the confluence of the persistent illusion that something needs to be done with the reality that nothing in fact can be done. In the face of inherent and immovable barriers to change, the only responsible course is to document that unhappiness and explain its causes.

\section{The Utilitarian Model}

Suppose we set out to establish a system of crime control with the single goal of minimizing the total cost of crime. Let us further suppose that we are completely unconstrained by retributive inhibitions against punishing the "blameless" or failing to proportion the severity of punishment to the degree of culpability. What would such a system look like?"10

10. I make no claim that the model described below represents the views of any particular individual. It is intended as a simplified composite, to which qualifications can be added.

The model has its origin in the works of Jeremy Bentham. See $1 \mathrm{~J}$. BENTHAM, AN INTROduction to the Principles of Morals and Legislation 1-12, 170-87 (1823) (1st ed. London 1789). The seminal modern formulation is presented in Becker, Crime and Punishment: An Economic Approach, 76 J. PoL. EcoN. 169 (1968). For some characteristic applications of the model, see Ehrlich, On the Usefulness of Controlling Individuals: An Economic Analysis of Rehabilitation, Incapacitation, and Deterrence, 71 AM. EcoN. REv. 307 (1981); Polinsky \& Shavell, The Optimal Tradeoff 
Traditionally, utilitarians have begun with the premise that the criminal justice system should minimize the sum of the costs of crime and crime prevention. Since everyone's welfare is included in the social calculus, the cost of crime prevention includes not only enforcement costs (police) and process costs (courts), but also the suffering imposed upon criminals made to undergo punishment.

Using this model to establish optimal punishment and enforcement levels involves a two-step process. First, one must set total prevention costs at a level that minimizes the sum of the costs of crime and its prevention. This level is achieved when we have incurred additional prevention costs up to the point at which the cost of prevention equals the cost of the crime being prevented. In any case where the marginal increase in the costs of imposing punishment on criminals fails to produce a larger marginal decrease in the cost of crime, the sum of crime and crime prevention costs has not been minimized, and the punishment is inefficient. Conversely, an increase in the severity of punishment (or the probability of its infliction) is always desirable so long as the social cost of the crime thereby avoided exceeds whatever costs the increase imposes.

Once we establish the optimal total for prevention costs, the next step is to achieve the proper balance between its two components: punishment and enforcement/process costs. We must, in other words, decide whether it is more efficient to invest in police and court personnel so as to catch and process a large number of criminals while reducing the sentence of each criminal caught, or to achieve the same aggregate expected punishment level by solving fewer crimes but punishing more severely those criminals who are convicted.

In one form or another, this model has profoundly influenced academic discourse on crime and punishment. But, for three reasons, virtually no one defends the model in this highly simplified form.

First, at least in this unsophisticated form, the model leaves no place for conditioning punishment on a showing of fault or proportioning the degree of punishment to the degree of fault. So long as one can show empirically that a given level of punishment minimizes the sum of the costs of crime and crime prevention, the model requires its imposition whether or not the defendant "deserves" this treatment. ${ }^{11}$

Between the Prohability and Magnitude of Fines, 69 AM. Econ. Rev. 880 (1979); Stigler, supra note 4. For a representative collection of readings, see ThE Economics of CRIME (R. Andreano \& J. Siegfried eds. 1980).

11. For example, the model provides no inherent reason why crimes themselves should be defined with respect to any mental element. It may be, in some cases, that the intent of the actor has some relationship to the efficiency of punishing him, but this relationship is only contingent, and where it does not exist, the model seems to require punishment without "fault." Nonutilitarians have had a field day attacking consequentialist theories on this ground. See, e.g., McCloskey, A Non-Utilitarian 
Second, unless one makes some complicating assumptions discussed below, the model permits extremely high (some might say barbarous) punishment levels. The cost of catching and convicting additional criminals is likely to be higher than the cost of increasing the punishment for those caught, especially when the punishment is in the form of fines that involve a mere fund transfer without deadweight loss. ${ }^{12}$ The model therefore suggests that the balance between punishment and enforcement levels should be heavily tilted toward punishment. Moreover, given certain empirical assumptions, the model also implies a willingness to threaten extremely harsh punishment in order to reduce the level of crime. To be sure, an activity should not be made criminal in the first place if the total cost of prevention exceeds the cost imposed by the activity. But if we assume no decline in the marginal effectiveness of punishment, and no increase in its marginal cost, the model also justifies threatening extremely harsh punishment. This result follows from the hypothesis that each increase in the penalty will result in its infliction on fewer people. Thus, at some point, the decline in the number of people on whom the punishment is inflicted will compensate for the increase in the suffering they must undergo. The result is that suffering is concentrated on a few individuals, without increasing aggregate costs. ${ }^{13}$

Third, whatever the model's normative merit, it simply does not describe-or at least does not appear to describe-our current system. Penalties are commonly thought to be proportioned to perceptions of moral fault. Those who believe that the common law naturally moves toward efficient solutions are therefore left to explain this remarkable divergence

Approach to Punishment, in Contemporary UtIlITARIanism 239, 239-59 (M. Bayles ed. 1968) (utilitarianism might require punishment of the innocent or insane); Von Hirsch, Desert, in PHILosoPHY OF LAw 573, 573-76 (J. Feinberg \& H. Gross 2d ed. 1980) (utilitarianism fails to justify punishment because it ignores desert). There is no doubt that these attacks have the capacity to make at least some utilitarians squirm. One example is Smart, supra note 8, at 69-73 (utilitarianism might require horrible, unjust punishment, but only as lesser of two evils). For a less ambivalent utilitarian response, see Rawls, Two Concepts of Rules, 64 PHIL. REv. 3, 3-13 (1955).

12. See, e.g., Polinsky \& Shavell, supra note 10, at 883 (if potential offenders risk-neutral, then optimal probability of apprehension as low as possible and optimal fine as high as possible). Here I assume that potential offenders are neutral in their attitude toward risk. If potential offenders are risk-averse, increasing the risk of apprehension makes the activity less attractive. See id. at 881 .

13. Suppose, for example, that shoplifting is presently punishable by one year of imprisonment, that at this punishment level 1000 people will commit the offense, and that each additional year of punishment will "buy" 100 fewer shoplifters. On these facts, it may not be efficient to raise the penalty to two years, since the increase in prevention costs (1800 person/years instead of 1000) may not be worth the decline in crime. On the other hand, increasing the penalty to ten years does not increase prevention costs since, at that level, only 100 people will commit the crime and punishing them for ten years imposes the same cost as punishing 1000 people for one year. It deserves emphasis that this point holds only so long as each additional unit of punishment "buys" a constant additional unit of deterrence. See infra pp. 329-34. So long as this is true it is possible to threaten higher punishment without having actually to incur the increased punishment costs, since the threat will reduce the undesirable activity to be punished. See infra pp. 323-24. 
between what the model prescribes and the anger and empathy people feel.

Much of the history of utilitarian thought about punishment consists of efforts to elaborate on the basic model to meet these objections. As a normative matter, utilitarians would like to incorporate the intuitions most of us have about the appropriate limits on punishment. ${ }^{14}$ As a positive matter, they would like to explain in efficiency terms the limits we in fact impose.

These attempts to tinker with the model so as to defuse the objections to it are bound to fail. The objections ultimately do not rest upon some minor flaw that prevents achievement of efficient outcomes, but rather on the nature of the enterprise. It is the very effort to achieve efficient outcomes that insures inefficiency.

The most venerable strategy utilitarians have used to domesticate their model has been to attack the empirical assumption that the deterrent efficacy of punishment remains constant as punishment levels increase. If, at high levels, a marginal increase in punishment costs buys a negligible decrease in the cost of crime, then an upper ceiling on punishment is efficient. According to this view, what we think of as distinctions between defendants based on moral fault are really no more than efforts to avoid wasting punishment costs on the least deterrable class of defendants.

As we shall see, ${ }^{16}$ this argument leads directly to a central paradox for utilitarians. Before evaluating it, however, it is necessary to address a

14. The role of intuitionism in assessing utilitarian theory-or, for that matter, in assessing any ethical view-is controversial. Some utilitarians have insisted that the role of their theory is to provide a rational check on intuitions that may result from superstition or over-emphasis on the welfare of present generations or specific groups. Some in this camp, however, have acknowledged that they must ultimately appeal to intuition to support the underlying principle of welfare maximization. See, e.g., Smart, supra note 8, at 62-67 (utilitarianism provides check on selfishness and short-sightedness); Sprigge, A Utilitarian Reply to Dr. McCloskey, in ConTEMPorary Utilutarianism 261, 270-72 (M. Bayles ed. 1968) (utility principle deeply felt sentiment against which other sentiments should be tested). Still others have expended considerable effort to make the implications of their theory consonant with common moral feelings. Posner, for example, specifically asserts that a moral theory should be rejected if it "yields precepts sharply contrary to widely shared ethical intuitions" and acknowledges that his "wealth maximization" approach is motivated largely by the desire to tame the "moral monstrousness" of utilitarianism. See Posner, supra note 3, at 110-19. Remarkably, Posner defends his theory on these intuitionist grounds, while acknowledging that it might support the following conclusions: (a) A good man would choose to kill a child rather than 100,000 sheep if they were worth more than any monetary value that could reasonably be ascribed to the child; (b) Some forms of forced racial and ethnic segregation are morally justified, at least if the disadvantaged group is not "productive"; (c) It is morally desirable for the state to prohibit parents from having children when "the expected social cost of additional population exceed[s] the expected product"; (d) A contract providing that the borrower's knees should be broken if he fails to repay the lender should be enforced by the state. See id. at 133-34. In contrast, he cites the "interventionist" proclivities of utilitarians and their tendency to favor "income equalization" in the course of demonstrating the "monstrous" consequences of utilitarianism. See id. at $116 \mathrm{n} .47$. All of which goes to show that the attractiveness of an intuitionist approach depends largely on whose intuitions you are talking about.

15. See infra pp. 329-30. 
number of efficiency arguments for limiting punishment, even on the assumption that its marginal productivity does not decline.

\section{A. Overdeterrence}

The simplest utilitarian objection to a regime of exceedingly harsh punishments is that it is inefficient because it overdeters crime. It is often stated with a confidence reserved for self-evident truths that the cost of the threatened punishment should not exceed the social cost of the criminal conduct if it were allowed to occur. ${ }^{16}$ As intuitively appealing as this claim may seem, however, it is based on a fundamental confusion: It is simply wrong to equate the cost of actually inflicting punishment with the cost of threatening it. If we assume no decline in the marginal productivity of punishment, then the cost of threatening harsher sanctions need not increase, because the number of cases in which it is actually necessary to inflict the sanction declines. Indeed, at some theoretical ceiling, the threat of truly hideous punishment becomes completely costless because it successfully deters all crime and, therefore, never need be imposed. ${ }^{17}$

Of course, it might still be argued that even threatened punishment imposes a cost by preventing the potential criminal from realizing the pleasure he would derive from his crime. On this view, the purpose of the criminal sanction is to force the potential criminal to internalize the social cost of his conduct. If he does so, and if the value to him of committing the crime outweighs the cost thereby imposed, the crime ought to occur. A penalty that is too high deters such "efficient" crimes, thereby decreasing aggregate utility. ${ }^{18}$ But the difficulty with this position is that it can be maintained only if one is prepared to value positively the pleasure a criminal derives from his crime. A person holding this view must therefore believe that it would be a good thing for a certain number of rapes, murders, and muggings to occur even if they could be eliminated at no social cost. ${ }^{10}$ This position is, at best, intensely

16. For example, Easterbrook asserts that "[t]he optimal price for the offense is just high enough to require offenders to pay for all of the harm their crimes inflict on the rest of us." Easterbrook, Criminal Procedure as a Market System, 12 J. Legal Stud. 289, 292 (1983). Instead of arguing for this proposition, he supplies a string-cite. Id. at 292 n.4.

17. See supra p. 321 . This argument puts to one side, for the moment, the possibility that the cost of error might be exaggerated by concentrating punishment on a few. See infra p. 325 .

18. See, e.g., Becker, supra note 10, at 190-93 (in system of fines, if value of unlawful act to perpetrator outweighs social harm, fines should equal sum of social harm and cost of apprehension and conviction, not value to perpetrator); Schwartz, An Overview of the Economics of Antitrust Enforcement, 68 GEO. L.J. 1075, 1081 (1980) (if value of unlawful act to perpetrator outweighs social cost, punishment should be equal to social cost).

19. This difficulty arises, I believe, because utilitarianism is radically incomplete as a moral theory. The theory tells us in great detail how we ought to aggregate preferences, but nothing at all about what preferences we ought to have. This lacuna leaves utilitarians open to the charge that they are unable to distinguish between the desires of torturers and gluttons on the one hand and those of 
controversial. ${ }^{20}$ But even if we accepted it, it would still imply extremely high penalties, since the cost of violent crime to the victim virtually always exceeds the benefit to the criminal.

The overdeterrence argument is more appealing when defendants raise a particularized defense based upon special circumstances. For example, a defendant who runs over a drunk lying across a narrow road to avoid colliding with an oncoming car filled with people arguably should not be punished-he has done precisely what we want him to do. In this situation, a defense is available because the defendant produced an outcome that is utility maximizing. ${ }^{21}$ The same defense may also be available even if the outcome is one we would prefer to avoid. For example, a defendant who engages in criminal conduct because of an authentic, nonnegligent mistake of fact should not be punished. Even though things turned out badly, he too has done what we would want him to do under the circumstances. ${ }^{22}$

This argument for limits on punishment proves either too little or too much. If the point is simply that socially desirable activity should not be criminalized, then the assertion is, of course, true, but hardly helpful. Acceptance of this trivial proposition tells us nothing about why we should limit punishment once the activity is defined as criminal. Perhaps the point is that even for conduct that is generally a crime, there is a need to make a more particularized cost-benefit analysis to take account of a defendant's special circumstances. But it would seem that most of the very clear cases where this is so could be accounted for in advance by the definition of the offense. When the case is closer, however, punishment is essential to force the defendant to internalize the social cost of his conduct, and hence to weigh that cost against the benefit to him of his crime. If the defendant understands that he will not be punished if his conduct maximizes social utility, he will always make this claim. Thus, a defendant who is aware that special circumstances are exculpatory may not weigh the cost of punishment in deciding whether to commit a crime. The only way to assure that a criminal has weighed the value of the crime to him

philosophers and philanthropists on the other. See E. CarritT, The Theory of Morals 40 (1928) (utilitarianism would require torture of innocent victims if pleasure of sadists outweighs pain of victims). Mill understood the nature of the problem at the beginning. See J.S. MiLl, UTILITARIANISM 18-20 (S. Gorovitz ed. 1971) (1st ed. London 1861). For a modern utilitarian response, see Smart, supra note 8 , at $25-27$.

20. For an argument that pleasure derived from criminal activity ought not to be positively valued, see Stigler, supra note 4, at 527-28.

21. See, e.g., G. Fletcher, Rethinking Criminai. Law 825 (1978) (breaking the law justifiable on utilitarian grounds when lesser of two evils).

22. See Brandt, supra note 8 , at 357. 
against the social cost is by threatening to punish him regardless of special circumstances. ${ }^{23}$

A final overdeterrence argument arises when the possibility of error is introduced. One might then contend that at high penalty levels, people would be deterred from engaging in innocent, socially useful activity for fear of being wrongly found guilty of crimes. If speeding were a capital offense, there would presumably be many law-abiding drivers who would leave their cars at home. ${ }^{24}$

This argument has some limited force. It must be remembered, however, that such overdeterrence would occur only in those instances where criminal and noncriminal conduct are closely allied and easily confused. For example, it is hard to imagine what socially useful activity would be deterred by extremely harsh sanctions for armed robbery. Moreover, while higher penalties may increase the importance of avoiding error, we could choose to invest the resources saved from fewer trials in more expensive but more accurate procedures.

\section{B. Underdeterrence}

Ironically, the more serious problem posed by very severe sanctions may be that they leave crime underdeterred. Optimal deterrence can be achieved only by maintaining a cost for more serious crimes higher than that for less serious ones. Thus, we would not want to make robbery punishable by death, since, if we did so, the robber might as well murder his victim. ${ }^{25}$ And some argue that if we take into account the possibility of error, a high penalty-low enforcement strategy might make all crime more attractive. This is so because the deterrent effect of punishment derives from the expected difference in treatment between people who obey and disobey the law. Error reduces this difference, and a high punishment-low enforcement strategy is said to exaggerate the effect of error by raising the stakes of each trial. ${ }^{26}$

Once again, however, these arguments have only limited force. It is true that deterrence requires maintenance of higher levels of punishment for more serious crimes. But so long as the marginal effectiveness of

23. The statements in text should be read in the context of the much broader argument between advocates of strict liability and advocates of fault-based systems of law. Compare, e.g., R. EPSTEIN, A TheORY OF STrict Liability (1980) with R. POSNER, supra note 6, at 137-42. The intricacies of that dispute are beyond the scope of this Article. It should be noted, however, that the assertions in the text may not follow when the defendant acts altruistically and therefore does not internalize the full benefit of his conduct.

24. See, e.g., Block \& Sidak, The Cost of Antitrust Deterrence: Why Not Hang a Price Fixer Now and Then?, 68 GEo. L.J. 1131, 1136-37 (1980) (danger of erroneous judicial inference of collusion deters some legal, efficient horizontal business behavior).

25. See Stigler, supra note 4 , at 527-28.

26. See Easterbrook, supra note 16, at 294. 
punishment remains constant, no inefficiency would result from the upward adjustment of all penalty levels. The argument therefore fails to explain why we do not simply shift our entire penalty structure upward while maintaining the marginal differences between crimes. While I suppose that there is some theoretical ceiling to the hideousness of the punishment humans can devise, the history of our species suggests few limits to our ingenuity.

Nor is it clear why the effect of error is exaggerated at high penalty levels. Although the consequence of each error would be more severe, the decline in the number of trials would presumably produce fewer total errors. Thus, unless one makes some special assumptions about attitudes toward risk, ${ }^{27}$ deterrence levels should not be affected. More fundamentally, even if such attitudes would lead to a decline in deterrence at high punishment levels, we can avoid the problem by pursuing the strategy that Professor Meir Dan-Cohen has labeled "acoustic separation."28

Professor Dan-Cohen argues that a legal command can be divided into a "conduct rule" addressed to the general public and a "decision rule" addressed to public officials. ${ }^{29}$ Sometimes it is an efficient strategy to invest resources in maintaining acoustic separation between these rules so that the general public is unaware of the decision rule being applied. ${ }^{30}$

This strategy is particularly useful in dealing with the problem of error at high punishment levels. It is, after all, not the fact of error but rather

27. In a regime of high penalties and low enforcement, there should be fewer errors (since there will be fewer trials), but the consequence of each error will be more severe. Risk-averse potential criminals will exaggerate the increased consequence of error and therefore will be overdeterred. Riskpreferring potential criminals will underestimate its importance and therefore be underdeterred.

28. See Dan-Cohen, Decision Rules and Conduct Rules: On Acoustic Separation in Criminal Law, 97 HARv. L. REv. 625, 630 (1984).

29. It is perhaps not altogether coincidental that this distinction can be traced back to Bentham. See J. Bentham, a Fragment on Government and an Introduction to the Principles of Morals and Legislation 430 (W. Harrison ed. 1948) (1st ed. London 1776 \& 1789), quoted in Dan-Cohen, supra note 28, at 626. Bentham himself, however, maintained that decision rules should be clearly conveyed to the general public. See J. BeNTHAM, A General View of a Complete Code of Laws, in 3 The Works of Jeremy Bentham 155, 161 (J. Bowring ed. 1843), quoted in DanCohen, supra note 28 , at 669 .

30. On the simplest level, acoustic separation is efficient because it allows us to threaten punishment without actually imposing it, thus gaining the benefits of deterrence without the deadweight loss of punishment. Cf. Dan-Cohen, supra note 28, at 673-77 (discussing tension between felt necessity and perceived evil of punishment). Of course, in the real world it is never possible to maintain complete acoustic separation. But Dan-Cohen argues that the vagueness of many statutes and the mixture of ordinary language and technical terms permit enough "selective transmission" of legal commands to make the strategy viable. See id. at 639-40, 658-64.

Although Dan-Cohen is ambivalent about the morality of acoustic separation, he is attracted to the strategy as a means of softening the law's brutality. See id. at 676-77. An argument he fails to consider fully, however, is that pursuit of such a strategy entails empowering some governmental agent to pursue it. While the strategy itself may be utility maximizing, it is less clear that giving the power to impose secret decision rules to government officials, who are necessarily shielded by acoustic separation from public criticism and control, would satisfy utilitarian criteria. 
the perception of that fact that causes suboptimal deterrence. ${ }^{31}$ Consequently, it might well be efficient for decisionmakers to use a high penalty-high error system so long as the perception of accuracy can be maintained.

Something quite like this phenomenon, in fact, seems to lie behind the widespread use of eyewitness identification testimony. There is by now a wealth of social science data demonstrating that such testimony is exceedingly unreliable, ${ }^{32}$ and that both witnesses and jurors tend to exaggerate the accuracy of identifications. ${ }^{33}$ The Supreme Court relied heavily upon this social science data in United States $v$. Wade ${ }^{34}$ and Stovall $v$. Denno ${ }^{35}$ where it enunciated a series of constitutionally-based exclusionary rules designed to control the use of eyewitness identification testimony. Unlike the exclusionary rules for searches and confessions, ${ }^{36}$ which presume that police are primarily motivated by the desire to reduce crime and that a legal rule is therefore necessary to force them to internalize the costs to privacy and autonomy, ${ }^{37}$ the Wade-Stovall rule is designed solely to promote accurate outcomes. Since such outcomes are essential to effective deterrence, the mystery is why the police should need additional incentives to avoid use of unreliable identification testimony. ${ }^{38}$

31. I have explored this point at greater length elsewhere. See Seidman, Faciual Guilt and the Burger Court: An Examination of Continuity and Change in Criminal Procedure, 80 Colum. L. REv. 436, 497-500 (1980).

32. Perceptual psychologists have established that the inability of people to receive and encode more than a limited number of stimuli at one time causes them to develop unconscious strategies of selective perception. In order to compensate for the gaps thereby created, witnesses tend to fill in the gaps, again unconsciously, with what they expected to see. Moreover, these initial perceptual distortions are aggravated by the exceedingly rapid decay of memory, which is also a selective and, to some extent, constructive process. Finally, even an initial perception that is accurate and is accurately stored in memory may be further distorted by the process of retrieval, especially if suggestive techniques are used. For an excellent summary of the social science data demonstrating these weaknesses in eyewitness identifications, see Note, Did Your Eyes Deceive You? Expert Psychological Testimony on the Unreliability of Eyewitness Identification, 29 STAN. L. REv. 969 (1977).

33. See id. at 970 and sources cited therein.

34. 388 U.S. $218,228-29$ (1967).

35. 388 U.S. 293,302 (1967).

36. See Mapp v. Ohio, 367 U.S. 643 (1961) (searches); Miranda v. Arizona, 384 U.S. 436 (1966) (confessions).

37. For the classic judicial formulation of this view, see Johnson v. United States, 333 U.S. 10, 13-14 (1948).

38. Dissenting from the Supreme Court's evisceration of the Stovall rule, Justice Marshall argued that suggestive identifications

pose a grave threat to society at large in a more direct way than most governmental disobedience of the law .... For if the police and the public erroneously conclude, on the basis of an unnecessarily suggestive confrontation, that the right man has been caught and convicted, the real outlaw must still remain at large. Law enforcement has failed in its primary function and has left society unprotected from the depredations of an active criminal.

Manson v. Brathwaite, 432 U.S. 98, 127 (1977) (Marshall, J., dissenting) (citation omitted). But it is far from clear which way these observations cut. If, as Justice Marshall asserts, accurate identifications serve the end of law enforcement, it would seem that law enforcement officers would have adequate incentives to eschew such procedures without the threat of an exclusionary rule. $C f$. Seidman, The Supreme Court, Entrapment, and Our Criminal Justice Dilemma, 1981 Sup. CT. Rev. 
A possible solution to the mystery is that, without constitutionally based constraints, it would be efficient for the police to follow a policy of acoustic separation by using unreliable identifications while depending upon the public perception of reliability to maintain a high level of deterrence. This separation is reinforced by procedural rules upholding the exclusion of expert testimony to inform the jury of the defects in identification testimony. ${ }^{39}$ Indeed, the Wade-Stovall rules themselves arguably do more to enforce the separation than to reduce error rates. ${ }^{40}$ The presence of an attorney at certain identification procedures enhances the illusion of accuracy while doing little to remedy the problems identified by perceptual psychologists. ${ }^{41}$ And the Stovall rule, especially as modified by the Burger court, ${ }^{42}$ excludes only the product of those identification procedures so obviously and egregiously unfair as to threaten public confidence in identifications generally..$^{43}$ It would be inefficient, therefore, for the police or the courts to invest resources in actually reducing error, even at high penalty levels, because the perception of accuracy is sufficient to maintain an optimal level of deterrence.

111, 144 (entrapment defense unnecessary on efficiency grounds).

39. See United States v. Amaral, 488 F.2d 1148, 1150, 1152-53 (9th Cir. 1973); People v. Johnson, 38 Cal. App. 3d 1, 6-7, 112 Cal. Rptr. 834, 836-37 (1974).

40. Social science research establishes that "suggestive procedures used to facilitate identification of the accused are only a minor cause of the unreliability of eyewitness testimony. Problems of perception and memory can often play a far greater role in producing an inaccurate identification." Note, supra note 32, at 994.

41. Even if the problem with identification testimony were police suggestiveness, it is not clear that the presence of a lawyer, who lacks the power to require a change in the procedure, would provide a remedy. See Read, Lawyers at Lineups: Constitutional Necessity or Av'oidable Extravagance?, 17 UCLA L. REv. 339, 362-67 (1969). But although lawyers do little to solve the real problem, the participation of the defendant's own representative surely enhances the legitimacy of the identification procedure in the jury's eyes.

42. In Manson v. Brathwaite, 432 U.S. 98 (1977), the Court held that the product of an unnecessarily suggestive identification procedure was admissible if the identification was otherwise "reliable." The holding is puzzling, to say the least. A court can know that the identification is reliable only from evidence about the crime. If this evidence is sufficient to convince the court of the defendant's guilt, then it should be sufficient in itself to support a jury conviction. A jury's deliberations are not enhanced by hearing about an unreliable procedure. Imagine a procedure where a witness selects the defendant by choosing a random name from a hat; other evidence convinces us that, by luck, the choice is correct. Could it seriously be maintained that the prosecution should be allowed to rely upon that random selection in arguing for conviction? Of course, suggestive show-ups and photographic identifications are not quite like picking a name from a hat. They are different precisely because a jury's ignorance of the social science data is likely to cause undue reliance on suggestive identifications. Manson leads one to conclude that the Court sought to exploit this undue reliance to secure more jury convictions. This strategy may in fact be efficient so long as the jury and general public remain ignorant of the inaccuracy of the trial outcomes it produces.

43. The lower courts have applied the Stovall-Manson rule in a manner that routinely permits identifications secured by all but the most outrageous procedures. See Allen v. Estelle, 568 F.2d 1108, 1111-14 (5th Cir. 1978); United States v. Marchand, 564 F.2d 983, 995-99 (2d Cir. 1977), cert. denied, 434 U.S. 1015 (1978). See generally Grano, Kirby, Biggers, and Ash: Do Any Constitutional Safeguards Remain Against the Danger of Convicting the Innocent?, 72 MICH. L. REv. 717, 719 (1974) (Supreme Court has "virtually immunized most pretrial identification procedures from constitutional challenge"). 


\section{Inefficiency Created by Punishment's Declining Effectiveness}

Of course, all of the discussion so far has been premised on the assumption that the marginal effectiveness of punishment does not decline. If one could show that such a decline occurs, then one could aim for the point where an increase in punishment costs no longer bought a decrease in the cost of crime, and where the increase is therefore inefficient.

While there may be an equilibrium point for all crimes beyond which further punishment is inefficient, utilitarians since Bentham have argued for limited punishment for certain classes of defendants, such as the insane, or for people acting in self-defense or under duress. ${ }^{44}$ Their rationale is simple: Since these people are less deterrable, punishing them is less efficacious. The same point applies to less structured, more typical sentencing decisions when a judge takes into account special facts about the defendant and the circumstances of the crime in imposing a penalty.

Given utilitarian premises, the argument for penalty ceilings based upon the declining effectiveness of punishment seems unassailable. This argument leads us, however, into a peculiar difficulty that might be called the sorting paradox. The paradox is created by the fact that every time a defendant violates the law, he demonstrates conclusively that he could not be deterred from doing so at the existing levels of punishment and enforcement. In principle, it will always be possible to find some characteristic of this defendant or his situation that makes him undeterrable. Once we discover this characteristic, we can define a class of potential criminals who share it, and who are thus undeterrable. The sorting paradox is that anyone who commits a crime always can be sorted into one of the categories of undeterrable people; accordingly, a utilitarian must find another justification for punishment besides deterring potential criminals, ex ante, from committing a crime.

Suppose, for example, that the penalty for first degree (premeditated) murder is life imprisonment, that 1000 people will commit second degree (unpremeditated) murder when the penalty for doing so is set at one year, that the number of murderers declines to fifty when the penalty is increased to ten years, but that those same fifty people will still commit second degree murder even if the penalty is increased to life imprisonment. On these facts, a utilitarian would find it efficient to distinguish between first and second degree murder, since eliminating the distinction (punishing all murder, whether premeditated or not, with life imprisonment) will not decrease the cost of crime. Utilitarians are likely to find the case for punishing fifty individuals for ten years attractive. While the fifty

44. See J. BeNThAM, supra note 10, at 170-74. For a modern utilitarian's use of the same argument, see Sprigge, supra note 14, at 291-92. 
people committing the offense are undeterrable at this punishment level, punishing them is nonetheless efficient because it deters 950 others, who are more influenced by the threat of punishment.

But a difficulty with this position is that the absence of premeditation is not all that makes a person resistant to the threat of punishment. Indeed, there must have been some other reason that the fifty people committing the murder were less deterrable than the other 950 . These fifty people were uninfluenced by the ten year penalty for some reason, perhaps because they acted in the heat of passion, or because the killing was necessary to defend themselves, or because they suffered from deprived childhoods, or because they are congenitally irritable. In theory, it would be possible to exculpate those who are undeterrable on any of these grounds-or, for that matter, on any grounds at all-without causing any of the 950 others, who do not fall into one of the stipulated categories, to commit the crime.

Is there a way out of the sorting paradox? A utilitarian might respond that the argument rests on unrealistic assumptions about our ability to define these categories and accurately place defendants within them. ${ }^{45}$ Punishment of persons who suffered deprived childhoods may be justified even if they cannot be deterred because if such individuals are not punished, some of the 950 people who are deterrable might be tempted to commit the crime and then wrongly claim this defense.

But this leaves us with what is at best an uneasy case for limits on punishment even at levels where its deterrent efficacy is small. About the most that can be said is that such limits can be justified in cases with a relatively low cost of identifying accurately the reason that a defendant was not deterred. Where the cost is high, and where the risk of sorting into wrong categories is great, harsh punishment is justifiable as socially beneficial even though the defendant himself, and those identical to him, could not be deterred by it.

On a positive level, it seems worthy of note that this version of our doctrines of mitigation and excuse largely ignores what actors in the system think of themselves as doing. The model tells us to focus solely upon the effect on others of punishing the defendant. But when judges exercise sentencing discretion or apply the law of excuse, they are also making judgments about the defendant himself and about what punishment he "deserves."

More significantly, the model ignores the possibility that the very failure to make these moral judgments produces the observed decline in the

45. To support adherence to general rules, rule utilitarians frequently rely upon the argument that individuals may make mistakes in calculating overall utility. See, e.g., R. BRANDr, supra note 8 , at 273 (individual may be incompetent to perform utility calculations). 
productivity of punishment at high levels. The model depends solely upon an unexplained empirical phenomenon. We simply notice that at certain levels, for certain crimes and defendants, punishment no longer produces the desired effect.

To some extent, the phenomenon may simply reflect the difficulties in communicating the existence of higher punishment levels to potential criminals, who do not, after all, typically consult the statute books before embarking upon a criminal adventure. But the failure of a given increase in the sanction to produce a commensurate decrease in crime does not mean that a still larger increase will also fail to produce the desired effect. It seems likely that even those potential criminals who remain oblivious to subtle variations in punishment levels will notice quantum leaps, especially if we are willing to stick with the harsher penalties for periods long enough to change expectations.

Alternatively, declining effectiveness may be explained by the natural tendency for punishment to be "front-loaded." Fines, for example, cannot exceed the amount of money the defendant has. At some point, then, increasing the theoretical size of the fine produces no increase in deterrence, and we must therefore resort to imprisonment. ${ }^{48}$ But much of the cost to the criminal of imprisonment-especially the initial humiliation and stigma-comes at the beginning of the term and is not increased by adding additional years. ${ }^{47}$ Moreover, the tendency of people to discount the future means that the threat of each additional year of imprisonment carries less deterrent impact. ${ }^{48}$

If front-loading were the whole story, however, we could readily solve our problem by using other forms of punishment in which severe pain is immediately inflicted. For example, widespread corporal and capital punishment for even minor offenses would be efficient. But experiments with attempts to inflict death or great bodily suffering for relatively minor crimes demonstrate that these high penalties are singularly inefficient. ${ }^{48}$

The difficulty with each of these solutions is that the very effort to put in place a no-fault utility-maximizing system of punishment causes the utility of punishment to decline. Harsh punishments for minor offenses do not work precisely because they depart from popular notions about how

46. See Coffee, Corporate Crime and Punishment: A Non-Chicago View of the Economics of Criminal Sanctions, 17 AM. CRIM. L. REv. 419, 433-36 (1980) (comparison of fines with incarceration suggests lesser deterrence value of fines).

47. See id. at 432 .

48. See, e.g., Block \& Lind, An Economic Analysis of Crimes Punishable by Imprisonment, $4 \mathrm{~J}$. LEGAL. STUD. 479, 481 (1975) ("marginal disutility of a prison sentence decreases with length of sentence").

49. See, e.g., J. Tobias, Grime and Police in England 1700-1900, at 139-47 (1979) (describing lack of deterrent effect of public executions in eighteenth century). 
people should be treated-notions we purport to adhere to for nonconsequentialist reasons. $^{\text {.0 }}$

On an intuitive level, it is apparent that the model described above would, if implemented, lead to serious problems. Where the model requires very harsh penalties that seem unjust or undeserved, the result would almost certainly be nullification and, therefore, actual sanctions would become less severe than they might have been under a system that permitted mitigation. ${ }^{\text {s1 }}$ Moreover, even if we could actually generate the penalties the model requires, the result would be a fundamental alteration of the nature of the criminal sanction.

Quite by accident, the law and economics literature provides some chilling insights into the law enforcement consequences of divorcing punishment from blame. It is interesting to note that proponents of an economic view of crime repeatedly rely on the model of the traffic violator to make their argument. ${ }^{\mathbf{6 2}}$ This choice of example is hardly coincidental. It serves the economist's heuristic purposes to choose for study a "crime" where we can imagine both the criminal and society rationally calculating costs and benefits without the encumbrance of moral feelings and inhibitions. Of course, for that very reason the example is highly misleading. As my colleague Silas Wasserstrom has remarked, a person reading this literature might suppose that when Americans complain about crime in the street, they are upset about overtime parking. Yet the example is also unintentionally revealing. It suggests that if we do succeed in remaking our criminal justice system into a means of imposing pain without blame, we will end up with exactly the sort of compliance we now achieve at a typical parking meter.

Similarly, in the course of arguing for a law enforcement strategy that combines severe penalties with low probabilities of apprehension, Richard Posner makes the following point:

It is sometimes objected that a system under which probabilities of punishment are low is unfair, because it creates ex post inequality among offenders: many go scot-free; others serve longer prison

50. In the next section, I advance a detailed argument for why punishment levels that do not correspond to perceptions of blameworthiness create inefficient outcomes.

51. It has been formally demonstrated that the setting of high, mandatory penalties may, through nullification, lead to a reduction in deterrent efficacy. See Note, Daring the Courts: Trial and Bargaining Consequences of Minimum Penalties, 90 YALE L.J. 597 (1981); see also Michael \& Wechsler, A Rationale of the Law of Homicide II, 37 Colum. L. REv. 1261, 1265 (1937) (widespread imposition of harsh penalties arouses sympathy for accused).

52. Thus, Frofessor Polinsky devotes his entire chapter on criminal justice to a discussion of double parking. See A. Polinsky, An Introduction to Law and Economics 73-84 (1983). Similarly, Gordon Tullock develops his economic theory of crime in the context of illegal parking and tax evasion-another "crime" often committed by segments of the population we are not disposed to blame. See Tullock, An Economic Approach to Crime, 50 Soc. Sc. Q. 59 (1969). 


\section{Utilitarian Theory and Crime Control}

sentences than they would if more offenders were caught. But to object to this result is like saying that all lotteries are unfair because, ex post, they create wealth differences among the players. ${ }^{\mathbf{5 3}}$

Professor Posner may or may not be correct about optimal enforcement levels, but he surely misunderstands the point of his own analogy. Many people have no moral qualms about playing the lotteries, and those who have a taste for risk will play them even when the odds are substantially unfavorable. Thus, if we make our criminal justice system look like a lottery, we can hardly claim surprise when potential criminals choose to play the game.

The evidence is all around us that large numbers of people are willing to play the crime game when the threatened punishment no longer communicates moral disapproval. From the disastrous effort sixty years ago to enforce Prohibition ${ }^{54}$ to the current and growing difficulty in deterring tax evasion, ${ }^{50}$ it is clear that people do not respond solely to the risk of loss unassociated with moral blame. Our experiences over the last forty-five years with enforcement of the selective service laws provide a particularly dramatic illustration. In periods of war, being a soldier can be at least as unpleasant, and certainly more dangerous, than serving a prison term. Consequently, if moral disapproval had no impact on conduct, one would expect young men to attempt to avoid military service in the same way that people generally attempt to avoid punishment. Of course, throughout history, a certain percentage of draft-eligible men have attempted draft evasion. But there have been many others who voluntarily embraced the pain and risks associated with war because, at least during popular wars, military service was perceived as praiseworthy rather than blameworthy. Conversely, in the recent past when military service seemed to some a source of shame rather than pride, the laws against draft evasion lost some

53. R. POSNER, supra note 6 , at 170 .

54. For a good account of how the effort to enforce Prohibition reduced the deterrent force of the criminal law, see A. Sinclatr, Prohibrtion: The Era of Excess 220-41 (1962). Sinclair quotes a witness before the Wickersham Commission who testified that:

there is not any feeling of resentment against [racketeers], because they are looked upon as being part of a trade to satisfy a social want. There is not a feeling of prosecution on behalf of the law even for the most vicious crime committed. It is all a reflection on the social mind. We seek by law to tell the people you can not do so and so, when the people are not in that frame of mind. . . They want their liquor. They do not care what chances the other fellow takes so long as they don't take the chance.

Id. at 227 (footnote omitted).

55. See Murray, IRS Is Losing Battle Against Tax Evaders Despite Its New Gear, Wall St. J., Apr. 10, 1984, at 1, col. 6 . 
of their deterrent efficacy. ${ }^{58}$ Draft evaders then became heroes and martyrs, and the harsher the sentence imposed, the greater their glory. ${ }^{57}$

\section{The Utilitarian Gase for Blaming}

It is at least plausible, then, that the failure to make the severity of sanctions correspond to public perceptions of culpability causes punishment to lose its effectiveness. If true, this conclusion would hardly come as a surprise to a rule utilitarian. It merely illustrates the more general proposition that there are occasions where adherence to a general rule (e.g., a person should be punished only to the extent he is at fault) maximizes utility even though specific applications of the rule appear to yield suboptimal outcomes. ${ }^{88}$ Indeed, on occasion, an unyielding insistence on a rule may maximize utility precisely because it conceals the fact that we are engaging in utility calculations. ${ }^{89}$

But how does adherence to a rule that limits punishment according to culpability maximize utility? The explanation begins with a distinction and some definitions. It is useful to distinguish between modes of enforcement based upon appeals to self-interest and modes of enforcement based upon the inculcation of moral inhibitions. ${ }^{60}$ By "appeals to self-interest," I mean incentive structures that promise the potential criminal more pain than pleasure if he performs the criminal act. By a "moral inhibition," I mean a disinclination to perform an act even when the actor perceives it to be in his self-interest-i.e., even when he anticipates that the act will yield more pleasure than pain. By "pleasure," I mean all forms of utility, in-

56. For statistics on the increased incidence of draft evasion and desertion during the Vietnam period, compare N.Y. Times, Jan. 22, 1977, at 1, col. 6 (10,000 draft evaders and nearly 100,000 deserters during Vietnam War) with Veysey, Extralegal Resistance, in LAw AND RFsisTaNCE 247-48 (L. Veysey ed. 1970) (4000 men in World War I and 18,000 in World War II refused to serve in army).

57. See Veysey, supra note 56 , at $246-48$.

58. See, e.g., J. Austin, The Providence of Jurisprudence Determined 38-39 (H.L.A. Hart ed. 1954) (general tendency of rule, not specific application, is correct utilitarian focus); see also supra note 9.

59. See Williams, A Critique of Utilitarianism, in J. Smart \& B. Williams, Utilutarianism: FoR AND AGAINST 75, 123-24 (1973). Once one acknowledges that a rule may be utility maximizing only so long as this effect is concealed, the possibilities for paradox become virtually endless. See, e.g., H. Sidgwick, THE METhods of Ethics 490 (1962):

[T]he Utilitarian conclusion, carefully stated, would seem to be this; that the opinion that secrecy may render an action right which would not otherwise be so should itself be kept comparatively secret; and similarly it seems expedient that the doctrine that esoteric morality is expedient should itself be kept esoteric. Or if this concealment be difficult to maintain, it may be desirable that Common Sense should repudiate the doctrines which it is expedient to confine to an enlightened few. And thus a Utilitarian may reasonably desire, on Utilitarian principles, that some of his conclusions should be rejected by mankind generally; or even that the vulgar should keep aloof from his system as a whole, in so far as the inevitable indefiniteness and complexity of its calculations render it likely to lead to bad results in their hands.

60. These categories roughly parallel Mill's distinction between external and internal sanctions. See J.S. MiLL, supra note 19, at 32-33. 
cluding the informal benefits derived from one's reputation as a morally good person and the sense of well being that comes from the knowledge that others approve of one's conduct. "Pleasure," however, does not include satisfaction derived solely from one's sense of having done the morally right thing. Conversely, I am using "pain" to mean all forms of disutility, including the suffering caused by being blamed by others. "Pain," however, excludes the sense of guilt or remorse that people feel simply because they think they have done the morally wrong thing, even when others are not blaming them. Finally, by "blaming," I mean not simply the attribution of causal responsibility, but rather the communication of moral condemnation based upon a perceived absence of moral inhibition.

It should be obvious that society depends upon both appeals to selfinterest and the inculcation of moral inhibitions to ensure compliance with social norms. Although the extent to which the threat of punishment actually deters crime is intensely controversial ${ }^{61}$ and probably unknowable, ${ }^{62}$ it can hardly be doubted that some people avoid criminal acts because of the threat of criminal sanctions. ${ }^{63}$ But it is certain as well that many others would refrain from criminal conduct even if there were no chance of punishment, simply because they believe that the conduct is morally reprehensible. ${ }^{64}$

Although a perfectly efficient criminal justice system would use some optimal mix of these two enforcement modes, it would rely upon moral inhibitions to the greatest extent possible. Control through moral inhibitions will often impose a smaller social cost per unit of prevention. If people can be persuaded to abstain from some crime even when criminal conduct is in their self-interest, we can avoid the social cost of structuring incentives that discourage crime. Anyone who doubts the enormity of these costs need only imagine the kind of police force and penalty system we would need if everyone were prepared to commit any crime he thought he could get away with.

61. Compare, e.g., Ehrlich, Participation in Illegitimate Activities: An Economic Analysis, in EsSAyS In THE Economics of CRIME ANd PUnishment 68-134 (1974) with Cook, Punishment and Crime: A Critique of Current Findings Concerning the Preventive Effects of Punishment, LAw \& Contemp. Probs., Winter 1977, at 164.

62. For a review of the methodological difficulties, see Cook, supra note 61, at 180-203.

63. See, e.g., F. Zimring \& G. Hawkins, Deterrence: The Legal. Threat in Grime ConTROL 76-77 (1973). It does not follow, however, that the overall level of crime is reduced by the threat of punishment. There is evidence that threats also make the prohibited activity more attractive to some individuals, at least in cases where the act is initially legal. See J. BREHM, A THEORY OF Psychological Reactance 118-19 (1966). Which effect predominates with regard to any particular offense and punishment level is a complex empirical question. See F. ZimRING \& G. HawkINS, supra, at 96.

64. Thus, even Bentham recognized that some crime was prevented by other motives such as benevolence, religion, or honor. J. BENTHAM, THE THEORY OF LEgisLation 229-30 (1975) (1st ed. London 1864). 
To be sure, convincing people to forego self-interest is not costless either. But we are likely to bear much of this cost in any event. Since many people purport to adhere to moral principles without regard for the costs or benefits they confer, they are likely to attempt to teach such principles to others whether or not it is efficient for them to do so.

While there are a variety of techniques for teaching moral inhibitions, one of the primary ways is by blaming those who violate the norm in question. ${ }^{65}$ Blaming is useful for teaching noninstrumental values because it is itself noninstrumental. We usually do not blame because we want to accomplish something, but rather, simply because the recipient of blame has done something wrong. ${ }^{\text {B }}$

Our most important collective institution for teaching through blaming is the criminal law. ${ }^{67}$ The symbolism and ritual associated with the criminal trial as well as the traditions surrounding criminal penalties make the criminal law an especially powerful tool for communicating blame. While we could conceivably eliminate the notion of blame from the criminal law, it would be inconsistent to use the criminal law to communicate blame and yet hold people who are perceived as blameless criminally responsible. It is therefore efficient not to punish blameless defendants so long as more crime is avoided by educating through blaming than is caused by foregoing deterrence.

Of course, there are some potential criminals for whom moral education will be impossible or the cost too high to be efficient. For them, we must use our fall-back technique of social control through appeals to selfinterest. But blaming, as a form of punishment, plays an important role in this process as well. ${ }^{68}$ Even people who are uninfluenced by moral educa-

65. For an empirical finding that blaming teaches moral inhibitions, see Grusec, Some Antecedents of Self-Criticism, 4 J. Personaltry \& Soc. Psychology 244 (1966).

66. As Richard Wasserstrom has written:

[I]t is difficult to develop a convincing consequentialist rationale for blaming. We can and do blame others silently, to ourselves. We can and do decide that those long since dead are properly to blame for things they did while alive; or that someone long considered blameworthy is, in fact, not blameworthy at all. . . . We can, of course, if pressed, construct a consequentialist account that takes these activities into account and justifies them on consequentialist grounds. But the arguments do not ring true.

R. WASSERSTROM, supra note 3, at 134. From these observations, Wasserstrom concludes that "consequentialist defenses of punishment are rendered suspect." Id. at 135 . But this conclusion is clearly a non sequitur. Blaming through punishment is an effective means of achieving desired consequences precisely because it is motivated by nonconsequentialist urges.

67. This point has been made most forcefully by Andenaes. See Andenaes, The General Preventive Effects of Punishment, 114 U. PA. L. Rev. 949 (1966). For a summary of the literature on criminal punishment as a means of teaching moral inhibition, see F. ZIMRING \& G. HAwKINS, supra note 63 , at $77-87$.

68. Alf Ross has made this point especially clearly. See A. Ross, ON GuILT, REsPonsibILITY AND PUNishment 37-38 (1975). 
tion may nonetheless fear the disapproval of others and may be deterred from engaging in conduct that may cause others to condemn them. ${ }^{69}$

There are two reasons why the pain associated with blame cannot simply be replaced by some other form of punishment that would provide comparable disincentives. First, blame makes the threat of other forms of punishment credible and therefore effective. One consequence of the sorting paradox described above ${ }^{70}$ is that the infliction of punishment can appear, ex post, to be irrational. This is so because the defendant can always maintain that he is a member of the class of undeterrable potential criminals upon whom punishment would be wasted. Punishment is rational only from the perspective of the criminal contemplating a crime ex ante. If we can make him believe that he will be punished, then perhaps the crime will be avoided. But the very irrationality of punishment after the fact tends to obstruct this communication and so reduce the deterrent force of the threat. ${ }^{71}$

One obvious way around this dilemma is for the person threatening punishment to precommit himself in a convincing manner. ${ }^{72}$ If the potential criminal can be made to believe ex ante that punishment will be forthcoming, even if it is irrational, then he is likely to be deterred from the crime. One especially effective means of communicating such precommitment is retributive rhetoric. A retributivist who believes in a moral duty to punish criminals can convincingly threaten punishment before the fact. Ironically, the very irrationality of his position ensures a utilitymaximizing result.

Moreover, blame not only makes the threat of other punishment credible, but also provides a kind of deterrence that other punishment cannot achieve. In separate treatments of criminal sanctions published a decade ago, Posner ${ }^{23}$ and Calabresi and Melamed ${ }^{74}$ argued that criminal sanctions had to be set at a level higher than that necessary to make the criminal internalize the social cost of his conduct. If the criminal's expected penalty were no more than the social cost, he would not be deterred from crime in cases where the conduct appeared efficient to him. But especially

69. For example, studies show that the stigma associated with welfare causes clearly eligible persons to refuse to participate in programs that would increase their income. See Moffitt, An Economic Model of Welfare Stigina, 73 AM. EcoN. REv. 1023 (1983). For a description of the mechanism through which stigmatization produces changes in behavior, see E. GoFFMAN, STIGMA: Notes on the Management of Spoiled Identity 5-10 (1963).

70. See supra pp. 329-30.

71. For a somewhat similar argument, see D. HodGson, supra note 9, at 85-90.

72. The classic explanation of how precommitment enhances bargaining power is found in $T$. Schelling, The Strategy of Conflict 21-46 (1980).

73. See R. POSNER, supra note 3 , at 358 .

74. See Calabresi \& Melamed, Property Rules, Liability Rules, and Inalienability: One View of the Cathedral, 85 HaRv. L. REv. 1089, 1124-27 (1972). 
in cases where transaction costs are low, it is important for society to recognize "property rules" that protect rights from unbargained-for divestiture even in situations where the transfer appears efficient. The criminal must therefore pay a special premium designed to prevent him from converting property rules into mere "liability rules" that would permit unbargained-for transfers when the transfer appeared to maximize utility.

Although neither Posner nor Calabresi and Melamed so argue, I believe that this premium must consist of the suffering caused by blaming. The association between the premium and blame is at least suggested by the fact that the two most important distinctions between criminal and tort liability are that the criminal law adds this special premium to punishment and that it punishes through stigmatization. But there is also another reason for believing that the association exists. If the premium consisted of any other penalty, no matter how high, a potential criminal who valued the criminal conduct enough might always be willing to pay the price. Since, by hypothesis, society would not blame such a person, it would in effect endorse the crime on efficiency grounds. Such an endorsement is inconsistent with the recognition of property, rather than liability, rules. But moral condemnation is a unique sanction because it inflicts suffering on individuals even when the conduct is otherwise efficient. Indeed, the condemnation is moral in character precisely because we are blaming an individual for preferring pleasure to pain in a situation where he should be obeying a categorical imperative. ${ }^{75}$ It would be inconsistent for a rule prohibiting efficient transfers to exist on the one hand and for violations to be tolerated solely because they are efficient on the other. Thus, only by blaming violators of property rules-by inflicting pain on them even if their conduct maximized overall utility-can we vindicate such rules.

If these observations are correct, then an efficient criminal justice system would set limits on the infliction of punishment that corresponded to perceptions of culpability. Of course, this fact alone need cause no discomfort to utilitarians. Utilitarian theory merely asserts that we should minimize the cost of crime and crime prevention. If punishment of the blameless is inefficient because the costs of such punishment are greater than the benefits we can expect from it, then withholding punishment is perfectly consistent with utilitarian theory.

This analysis, however, raises an additional question. Assuming pun-

75. True, a person who places a high enough value on the gains from criminal conduct may be as willing to endure this condemnation as any other penalty. Condemnation therefore does not assure perfect compliance with property rules. But there is no inconsistency between the existence of a rule and toleration of some noncompliance. 
ishment ought to be limited to those who are blameworthy, whom should we blame? Once again, a utilitarian's answer to this question is relatively straightforward: We should blame individuals when doing so will maximize utility-i.e., when the suffering imposed upon those who are blamed is counterbalanced by the social benefit resulting from the change in behavior.

But it is here that utilitarian theory begins to contradict itself. As argued above, blaming is a unique sanction in that it is conferred on moral rather than consequentialist grounds. Thus, an awareness that blame is being distributed in order to maximize utility seems bound to undercut the deterrent effect that justifies the distribution. ${ }^{76}$

By itself, this objection need not be fatal to the theory. In the first place, it may well be possible through acoustic separation to conceal the utilitarian justification for blame. As long as criminals continue to believe that condemnation is deserved, it will retain the deterrent efficacy that justifies it.

Moreover, there is also a second, less cynical, response. As Elizabeth Beardsley has shown, it is possible for people simultaneously to maintain different moral perspectives with respect to praise and blame. ${ }^{77}$ Thus, as a student of our society, I can see that we are better off with the institution of blaming because it produces good consequences. From this perspective, it hardly matters how this institution came about. I might believe in a sociobiological explanation, or that we are fulfilling God's will when we blame, or even that we are just "lucky" that people act in this way. Whatever the explanation for its origins, as a utilitarian I would be happy with this state of affairs and would not try to alter it, even if I could, because it maximizes welfare.

It does not follow from this abstract knowledge, however, that I myself am obstructed in my ability to blame others in everyday life or shielded from pain when others blame me. Nor does it follow from the theory, and my knowledge of it, that I am personally motivated by the desire to maxi-

76. As D.H. Hodgson has written:

[I]t is just the implication that the act or person praised or blamed is good or bad that gives praise and blame their distinctive effectiveness. If a person knows that another is praising or blaming him solely on the basis of the consequences of the praise or blame, he may possibly be influenced, simply because he likes praise and dislikes blame, whether or not they are deserved. But (i) the distinctive effectiveness of praise and blame, which sets them apart from other goods conferred and evils imposed upon one in respect of one's conduct, depends upon the recipient's believing that they are deserved, and thereby being gratified and encouraged or made repentant; and (ii) praise and blame come to be liked and disliked because they are given where they are (thought to be) deserved, and if it is known that they are being conferred on other grounds, their effectiveness in this way too may be lessened.

D. HodGSON, supra note 9, at 58 (emphasis added).

77. Beardsley, Deterninism and Moral Perspectives, 21 PhiL. \& Phenomenological ReSEARCH 1 (1960). 
mize utility when I blame. As an actor I can desire certain outcomes for reasons that have nothing to do with utility maximization. As an observer of my own conduct, I can then say that I do not wish to change that conduct because, whatever its motivation, it, fortunately enough, maximizes utility. Paradoxically, the conduct continues to have this good effect so long as those blamed realize that the conduct is not motivated by the consequences that morally justify it.

This argument leads us, however, to another, more serious, difficulty. We have proceeded on the assumption that the way in which blame is distributed is utility maximizing. But there is no inherent reason to believe that this is so. As an institution, blaming potentially serves to minimize the social cost of crime, but this fact provides no guarantee that the choice of people to blame will necessarily have similar good consequences. Moreover, because blaming produces good consequences only when it is not motivated by the desire to produce them, we cannot set out deliberately to change the way people blame so as to maximize utility. Thus, perceptions of blameworthiness form a fixed point around which we must build our criminal justice system.

In fact, I believe that the distributive function served by blaming inevitably pushes us toward inefficient outcomes. Part III attempts to explain why this is so.

\section{The Distributive Function of Blaming}

Thus far, our discussion of utilitarian theory has been confined to an examination of strategies for reducing the total social cost of crime. Even if we achieved a utility-maximizing solution to this problem, however, we would still face the issue of how that cost should be distributed. ${ }^{78}$ This distributional problem has two aspects. First, when confronted with two inconsistent activities, we must decide which to discourage in order to avoid the cost of conflict. We must, in other words, decide who will be the criminal and who will be the victim. It may be, for example, that either raising the penalty for unauthorized use of a motor vehicle or imposing criminal penalties on owners who leave their cars unlocked will be equally effective in reducing the number of car thefts. Which course-or combination of courses-we choose reflects no more than how we prefer to distribute the cost of control.

Second, even if we are clear as to the identity of the criminal and victim classes, there are choices to be made regarding distributional costs within

78. My thinking about the distributional issue has been profoundly influenced by a paper that, unfortunately, remains unpublished. See C. Goetz \& W. Schwartz, "Unequal" Punishment for "Equal" Crimes: An Economic Rationale (1976) (on file with author). 
the criminal class. So long as criminals are unable accurately to sort themselves in advance, we may have substantial freedom to lessen the costs for one class of criminals while maintaining the same level of overall deterrence by increasing the costs for another class. For example, the police must decide which streets to patrol with unmarked police cars. If we assume that burglars are unlikely to know which choice is made, but that they will be sensitive to overall levels of enforcement, we can resolve this distributional issue in a number of ways without affecting total enforcement costs.

How should we resolve such distributional issues? Traditionally, our resolution of them has been infused with the rhetoric of choice and blame. The most sophisticated effort to utilize this rhetoric and to make it compatible with utilitarian premises is found in H.L.A. Hart's classic essay on distributional issues. ${ }^{28}$

Hart argues that it is utility maximizing to distribute punishment in a manner that allows people a fair chance to choose whether or not to risk infliction of criminal sanctions. ${ }^{80}$ Without this limiting principle, we would all live in continual fear of suddenly becoming criminals. The psychic costs that would thereby be imposed far outweigh the deterrent gains achievable by punishing persons who did not freely decide to violate the law. It follows that defendants should be exculpated when they break the law in response to pressures that ordinary people would be unable to resist.

As stated, this argument is vulnerable on a number of grounds. First, even if correct, it responds only to the second distributional issue and not at all to the first. Hart tells us, in other words, which criminals we should punish, but not which acts we should make crimes. ${ }^{81}$

Second, it is unclear why one should exclude the threat of punishment itself from the catalogue of factors bearing upon the potential criminal's choice. It may be true that mental illness, external coercion, or innocent mistake deprive some people of a fair chance to avoid crime. But if deterrent theory makes any sense at all, some people are also influenced by the legal consequences of their conduct. Once this fact is acknowledged, the "free choice" theory can be turned on its head. Adequate punishment ac-

79. See H.L.A. Hart, Punishment and Responsibility: Essays in the Philosophy of LAW 158-85 (1968).

80. Id. at 181-82.

81. Moreover, the argument is premised on assumptions about "free will" and unfettered choice that anyone with determinist inclinations would find incoherent. At a minimum, advocates of the theory must supplement it with some method for disentangling the exercise of will from the external factors influencing it. Accomplishing this task is, to say the least, problematic. For Hart's effort to deal with this difficulty, see Hart, Legal Responsibility and Excuses, in DETERMINISM AND FREEDOM IN THE Age of Modern Science 95 (S. Hook ed. 1961). 
tually serves the interest of potential criminals since it prevents them from committing crimes that might otherwise tempt them. Put differently, there is no reason why the absence of adequate punishment should not be deemed just as coercive as any other factor influencing the defendant's choice. The very failure to threaten adequate punishment for the potential criminal may therefore deprive him of a "fair chance" to avoid crime. ${ }^{\mathbf{2 2}}$

Finally, and most significantly, whatever the theoretical attraction of a "free choice" theory, it simply fails to describe existing law. Most of our law of exculpation is based on a theory of rights rather than a theory of choice. Suppose a poor man, desperately in need of money to feed his family, burgles the house of a rich man who will barely miss the stolen property. The rich man, in turn, uses nondeadly force to drive the burglar away. The law is perfectly clear that the poor man is guilty of an offense, ${ }^{83}$ but that the rich man is not. ${ }^{84}$ While the rich man has a right to privacy in his home and the undisturbed possession of his property, the poor man has no right to help himself to this property even if he needs it more than does the rich man.

This allocation of rights may be quite defensible in terms of efficiency. There is at least a plausible case to be made for the institution of private property and a rule that property rights cannot be involuntarily extinguished whenever another person claims that a change in ownership will maximize utility. ${ }^{85}$ But the allocation cannot be defended on a "free choice" theory. The rich man's right to use force does not turn on a showing that his will was overborne by the attack. His claim depends not upon the coercive impact of the burglar's conduct (which may in fact be slight) but upon his right to be free from this type of coercion. Conversely, our society, at least, recognizes no general right to be free from the kind of economic coercion inherent in a capitalist economy. Even though the poor man may have burgled the house in response to pressure far more severe than that suffered by the rich man, he has no defense to the charge.

Thus, the principle of distribution Hart defends is both descriptively and theoretically problematical. But Hart is surely right that a theory of criminal justice requires some principle of distribution. Moreover, even

82. Robert Nozick has argued that a person is not coerced into performing an action if he does so in response to an offer rather than a threat. Whereas a rational person would be willing to move from a pre-offer to an offer situation, he would not be willing to move from a pre-threat to a threat situation. Nozick, Coercion, in Philosophy, Science, AND Mermod 440, 458-62 (1969). Since a rational potential criminal might well prefer to have incentives structured in a way that caused him to avoid crime, Nozick's position supports the conclusion that it is the absence rather than the presence of punishment that is coercive.

83. It is well established that "economic necessity" is no defense to a criminal charge. W. LAFAVE

\& A. ScotT, Handbook on Criminal Law 384 (1972).

84. Most jurisdictions permit use of nondeadly force to protect property. See id. at 399-400.

85. See supra pp. $337-38$. 
though our actual principle cannot be made to correspond to a "free will" theory, it is significant that he and others attempt to defend it on this ground. The defense is necessary because the communication of blame is not only a technique we utilize to minimize the total social cost of crime, but also a psychological mechanism we depend upon to justify the distribution of the cost among various groups. Believing that the people made to bear disproportionate costs in some sense chose to do so allows us to believe that they are to blame and that the distribution is morally justified.

But if "free choice" is not our actual principle of distribution, what is? It seems to me far more plausible that the distribution of the cost of crime reflects no more than the outcome of a political struggle between groups competing to achieve results advantageous to themselves and to those with whom they identify. It is rational for such groups to be concerned not only with the total cost of crime, but also with the percentage of the cost that they and their allies will bear. They therefore utilize their political power to shift those costs to others. Although the rhetoric of blame and choice is an important weapon in this struggle, it is exactly backwards to suppose that we impose costs on persons because they are blameworthy. Rather, declarations of blameworthiness are the way we announce the outcome of the struggle to distribute costs. ${ }^{88}$

A simple example may be useful to illustrate these points. Consider the following argument: Reducing the levels of enforcement and punishment will reduce the level of criminal violence. This seemingly bizarre conclusion follows from the fact that public enforcement and private prevention are alternative means of reducing crime and that there is an inverse relationship between them. ${ }^{87}$ As the level of public enforcement goes up, the

\section{As Kelly Shaver has written:}

Suppose that you are asked to evaluate the personal worth of a suffering victim. Let us assume that you do not want to believe that you yourself might have to undergo such pain. If that is the case, you cannot conclude that the victim is suffering "by chance," since that would raise the possibility that similar bad luck might befall you. Under these circumstances there are only two attributionally acceptable possibilities. First, you might see the person as being responsible (in the production-of-action sense) for his own suffering: "If he had been minding his own business, he wouldn't have been hurt." This sort of attribution would permit you to comfort yourself with the knowledge that jou would not have behaved as stupidly and therefore would not have received the same fate. Alternatively, if you were convinced that the person was not production-of-action responsible for his predicament, you might still protect yourself by asserting that the victim was morally reprehensible (the moral accountability sense of responsibility) and thus deserved what he was getting.

K. Shaver, An Introduction to Attribution Processes 106 (1975).

There is a considerable body of evidence demonstrating that attribution of moral responsibility in fact serves this self-protective function. See id. at 106-11; Heider, Social Perception and Phenomenal Causality, 51 Psychology REv. 358, 368-70 (1944); Shaver, Defensive Attribution: Effects of Severity and Relevance on the Responsibility Assigned for an Accident, $14 \mathrm{~J}$. PERSONALITY \& Soc. PsYcHologY 101 (1970).

87. On the interrelationship between public enforcement and private protection, see Bartel, An Analysis of Firm Demand for Protection Against Crime, 4 J. Legal Stud. 443 (1975); Komesar, A 
level of private initiatives to deter crime (e.g., avoiding dark alleys, purchasing alarms, forming neighborhood watch committees) are likely to decline. Conversely, as public enforcement levels are reduced, one would expect more private initiatives. At present crime levels, it would probably be efficient for potential victims to bear a greater percentage of the social cost of crime because they are likely to be the least cost avoiders. It is almost certainly less costly for a homeowner to install a more effective lock on his door, and so prevent a burglary, than it would be to apprehend, try, and punish the burglar after the fact. Moreover, private enforcement levels allow individual potential victims to fine-tune the level of protection according to the value they set on crime avoidance. Reducing enforcement levels would increase incentives for potential victims to take such preventive methods. Since these methods are more efficient, we could then expect less crime at any given level of social cost we wished to absorb to avoid crime.

Of course, this argument might be subject to both theoretical and empirical challenge. The point I wish to make is not that it is necessarily correct, but that it is at least plausible, and that even if it could be shown to be right, it is doubtful indeed that we would ever adopt the program it implies. In fact, there is precisely no chance that our political institutions could be persuaded to tell potential victims of criminal violence that they must remain cowering in their barricaded homes so that the criminals who prey upon them can avoid the cost of punishment. An opponent of such a program would surely argue that since criminals are blameworthy for creating the social cost of crime, they, rather than blameless victims, should bear the cost of crime prevention. But although this perception certainly corresponds to the intuitions of most of us, it is worth pausing to analyze the function served by the assignment of blame in this context. The opponent cannot be saying that it is efficient to blame the criminal since, by hypothesis, we would have less crime at the same cost by "blaming" the victim and forcing him to take self-protective measures. Rather than reducing the cost of crime, the act of blaming announces and justifies our conclusion concerning how that cost will be distributed. This distribution is problematical since it may not be utility maximizing. But as a political matter, it is probably inevitable because dominant groups will be indifferent to increases in total social costs if they are able to effect the distribution of those costs that they prefer.

Because most of us share the moral intuitions that assign blame to the criminal rather than the victim, it may seem farfetched to suppose that it could be otherwise. It is therefore instructive to compare the example dis- 
cussed above with our treatment of sex offenses against women. At least until recently, it was often supposed that rape victims were "asking for it" and therefore deserved precisely what they got. ${ }^{88}$ Our treatment of rape defendants, and the resulting distribution of costs between criminals and victims was, of course, influenced by this moral perception ${ }^{89}$ Although the matter does not lend itself to empirical demonstration, it seems plausible that these moral perceptions were related to the relative political powerlessness of women. As the political power of women has grown in recent years, women have become better able to influence distributive outcomes. ${ }^{90}$ The result is a change in moral intuitions so that rapists are now viewed as more morally blameworthy and women as innocent victims. ${ }^{91}$

It does not follow from all this that individuals attempting to influence

88. See, e.g., Whisner, Gender-Specific Clothing Regulation: A Study in Patriarchy, 5 Harv. WOMEN's L.J. 73, 114-17 (1982) (discussing judge's remarks about effect of women's provocative clothing on defendant changed with sexual assault).

89. A whole series of special legal rules for rape prosecutions were premised on the assumption that rape victims were responsible for their predicament. For example, in some jurisdictions, a woman was treated as having consented to the attack unless she "resist[ed] to the utmost." B. BABCOCK, A. Freedman, E. Norton \& S. Ross, Sex Discrimination and the Law: Causes and Remedies 827 (1975). The defense was permitted to put the victim's character and reputation in issue as evidence of her consent, and special corroboration requirements were imposed. See id. at 830, 843-53.

90. For a summary of recent changes in the law on consent, corroboration and the victim's character, see W. Williams, Babcock, Freedman, Norton \& Ross, Sex Discrimination and the Law: Causes AND Remedies 200-05 (Supp. 1978).

Two recent incidents in Washington, D.C. and Madison, Wisconsin serve as interesting counterpoints and illustrate how views about responsibility change with shifts in political power. In the Washington case, a local judge permitted two well-to-do teenage defendants to remain in the community prior to trial on felony charges growing out of a knife attack on a homosexual man. When each defendant pled guilty to one count of assault with a dangerous weapon, each was placed on one year's probation. The government's evidence showed that the defendants had met the complainant in a bar and asked him to join them at a party. When the complainant agreed, they drove him instead to a secluded park where they repeatedly kicked him in the groin, slashed him with a knife, and urinated on him. The complainant eventually escaped and ran through the woods naked and bleeding until he arrived at a nearby house and sought help. The judge rejected the government's request for a substantial period of incarceration because he was "satisfied" the teen-agers were drunk at the time . . . and that they were defending themselves from a sexual advance by the victim." Valente, 2 St. John's Sludents Given Probation in Assault on Gay, Wash. Post, May 15, 1984, at 1, col. 2.

Compare the actions of a Madison, Wisconsin judge who also imposed a one year suspended sentence on a 15-year-old defendant who pled no contest to a charge of second-degree sexual assault against a woman. The judge stated that the sentence was appropriate because women brought such attacks on themselves by wearing provocative clothing. See Whisner, supra note 88, at 114-15. In this case, however, the judge's comments sparked a political firestorm which culminated in his recall from office. His replacement was a woman. See W. Williams, supra, at 206.

91. Nor is this phenomenon restricted to the battle between criminals and victims. There is also a political struggle between classes of potential criminals. For example, I have argued elsewhere that the entrapment defense is best understood as an attempt to prevent the government from redistributing the cost of deterrence to potential criminals likely to exercise significant political power. See Seidman, supra note 38 . Although playing out the analysis in the context of different legal rules would be a complex task, well beyond the scope of this paper, I believe that a wide variety of other defenses and excuses are subject to similar explanation. Kelman, for example, has shown how virtually all criminal law doctrine depends upon our "interpretive construction" of a factual situation. Only after this undefended, often unconscious, process occurs does rational legal discourse take hold. See Kelman, Interpretive Construction in the Substantive Criminal Law, 33 STAN. L. REv. 591, 591-642 (1981). 
distributional policy always act selfishly. People may sometimes act altruistically to protect others with whom they in some sense identify. Moreover, the kinds of alliances people form to wage these political battles resist facile characterization. ${ }^{92}$ For example, one could interpret our failure to adopt the low enforcement, self-protection strategy described above as a kind of subsidy for persons without the economic means to protect themselves from crime-hardly the result a dogmatic Marxist would expect.

Thus, it would be a difficult task to create a model that predicted outcomes of the distributional struggle in all their complexity. But the important point for present purposes is that the struggle is, in essence, political rather than moral. Our political institutions simply distribute the cost of crime in a manner that reflects the preferences and power of competing groups. We then utilize the rhetoric of blameworthiness to cover our moral confusion about the justification for this distribution.

\section{Soldiers, Martyrs, and Griminals}

The previous two sections argue that the communication of blame serves two distinct functions. On the one hand, blaming is necessary to vindicate property rules and reduce the total cost of crime. On the other hand, blaming provides an ideological justification for the distribution of those costs. What remains to be considered is the manner in which the conflict between the functions produces outcomes that fail to minimize the total cost of crime and crime prevention.

We have already seen how preoccupation with the distributional problem produces one kind of inefficiency. Dominant groups have a strong incentive to adopt distributional policies that fail to minimize the total cost of crime as long as those policies make others bear the cost. But the clash between cost distribution and cost minimization goals creates the potential for a second kind of inefficiency that may be more serious in the long run. This difficulty stems from the debasement of the rhetoric of blame that occurs when it is used to justify distributional outcomes. As argued above, ${ }^{93}$ there is no necessary contradiction between the good conse-

92. Empirical research suggests, for example, that voter behavior is generally not determined by self-interest, at least in the short-term, material sense. Instead, voters seem more influenced by "symbolic attitudes." See Sears, Lau, Tyler \& Allen, Self-Interest vs. Symbolic Politics in Policy Altitudes and Presidential Voting, 74 AM. Pol. Scr. REv. 670, 676 (1980). The evidence, however, is consistent with the view that "self-interest operates indirectly through perceived shared group interests. By this argument, unsophisticated voters, having difficulty calculating what political posture is interestmaximizing, support the political positions taken by some group whose outcomes in private life seem over the long term to be correlated with their own." Id. at 681 .

For examples of literature on how people choose which group to join in order to advance their ends, see Komorita \& Chertkoff, A Bargaining Theory of Coalition Formation, 80 Psychology Rev. 149 (1973); Lawler \& Youngs, Coalition Formation: An Integrative Model, 38 SocromerRy 1 (1975).

93. See supra pp. 339-40. 
quences that flow from blaming and our awareness of these consequences. But it is less clear that blaming would remain a useful tool for reducing the total social cost of crime if moral condemnation were seen merely as a method of identifying losers in a distributional struggle. This realization might produce a crime control strategy that resembles the severe sanction, no-fault model described in Part I.

At first, it may seem that we presently run little risk of adopting such a strategy. Certainly, the general public and actors in the system do not perceive it as operating in this fashion. On the contrary, retributivist rhetoric seems to be on the ascent. ${ }^{94}$ But a peculiarity of moral condemnation as a form of punishment is that its efficacy depends upon the cooperation of the condemned. Limiting sanctions to persons the public believes are culpable is therefore a necessary, but not sufficient, condition for an efficient criminal justice system. Those punished must also believe the rhetoric of blame and accept the legitimacy of their punishment. The system begins to unravel if deviant subgroups believe that this rhetoric serves a cost-distribution function..$^{98}$

If this belief ever became widespread, we might become caught in a downward cycle of violence. Because criminals would then reject the moral legitimacy of the criminal sanction, they would view themselves as soldiers who bear the risk of punishment as an occupational hazard. ${ }^{96}$ Worse yet, when the risk became a reality, they and their peers would perceive themselves as martyrs fighting an unjust social order. ${ }^{97}$

\footnotetext{
94. See Seidman, supra note 31 , at $486-89$.

95. As Erving Goffman has written:

[I]t seems possible for an individual to fail to live up to what we effectively demand of him, and yet be relatively untouched by this failure; insulated by his alienation, protected by identity beliefs of his own, he feels that he is a full-fledged normal human being, and that we are the ones who are not quite human. He bears a stigma but does not seem to be impressed or repentant about doing so.
}

E. Goffman, supra note 69, at 6. See also J. Gibbs, Crime, Punishment, and Deterrence 84-86 (1975) (out-groups may be less prone to view punishment as stigmatizing since ignoring legal considerations may testify to solidarity among the exploited).

96. See, e.g., J. Allen, assault with a Deadly Weapon: The autobiography of a STREeT CRIMINAL 37, 122 (1977):

The only big shots I've been personally involved with have made it . . . through drugs or numbers or something like that . . . . [W] Wen I think about who's got the power in my neighborhood, I mostly think about people who've got to the top in strictly illegal ways. . . . IIn jail, I found that] a lot of dudes I knew were already there, and I just kind of fit right in. Myself and quite a few of my friends, we been in and out so much that we automatically [knew] the dudes that ran things.

97. See, e.g., the comments of "Jack," quoted in B. JAckson, In the Life: Versions of THE Criminal. Experience 94-96 (1972) (emphasis in original):

To me the criminal code is bullshit. The very guys that promulgate it are the ones that violate it. . . . [W]e're put in prison for violating laws, they are behind the shield and can do the very same things we are behind bars for. To criminals they can. I know they're not going to go up to you and hit you over the head or put a wire to your testicles, you know they just won't do it, but to people like me they will, to people in my element. 
One might suppose that we could achieve more efficient outcomes simply by distributing the cost of crime to maximize utility. But dominant groups will block this solution because it would result in a distribution contrary to their intuitions of culpability. The result is a vicious cycle. Increases in crime caused by the failure to communicate blame effectively produce political pressure for more, rather than less, punishment. Moreover, the shocking lack of moral inhibition demonstrated by criminals produces a reciprocal loosening of restraint. Perpetrators of criminal violence are increasingly perceived as subhumans, deserving no sympathy and possessing no rights. The growing concentration of punishment is also accompanied by ever shriller rhetoric of blame necessary to justify it. That rhetoric, in turn, lays the political groundwork for still harsher sanctions.

Of course, these changes do not go unnoticed among potential criminals. As statements of blame become more extreme to justify an increasingly lopsided distribution, they become correspondingly less effective as a means of crime control. Instead of eliciting feelings of guilt and remorse, they produce only a growing sense of victimization and hostility. ${ }^{98}$ For those on the receiving end of criminal justice, the system begins to resemble the malevolent lottery of Shirley Jackson rather than Richard Posner's benign game of chance. Accordingly, moral restraints are loosened further, and the whole sickening cycle repeats itself.

To be sure, potential criminals who no longer believe that punishment is deserved could still be coerced into a kind of sullen compliance. But the enforcement cost would be very high. Because moral inhibitions cannot be taught without the effective communication of blameworthiness, there would have to be a cop on every street corner to stop crime. Because property rules cannot be vindicated in an efficient no-fault criminal justice system, people would simply take what they could get away with.

It is an open question whether we have been, or will be, trapped in this cycle. We should not underestimate the capacity of dominant groups to obscure the distributional function of blaming and thus avoid or at least delay these consequences. ${ }^{99}$ Moreover, we may, in the end, be saved by

98. See, e.g., J. Allen, supra note 96, at 36:

There's conflict in there because my kind of crime is generally looked down upon, but the white-collar crime is an altogether different bag. Like Ehrlichman deciding when he wants to go to jail. Don't nobody tell me $I$ can decide. If they wanted to come and get me today, they could do it .... [I] can't fault him, but I can be mad with him. To think about it, say damn,

here's a dude that can tell the judge, "Well, look, I'm ready to start my time now." It's strange.

99. For example, Alpert and Hicks found that most of the prisoners they interviewed did not have a strongly negative attitude toward the law and the judicial system. See Alpert and Hicks, Prisoners' Atitudes Toward Components of the Legal and Judicial Systems, 14 CRIMINOLOGY 461, 470-73, 479 (1977). Fairchild's survey of prisoners found that although most of them were dissatisfied with the performance of American government, a majority had "internalized the basic ideology ... with its belief in freedom from governmental control, equality of participation, and guarantees of political 
demographic and socioeconomic factors that reduce the rate of crime, ${ }^{100}$ thereby defusing the political impetus toward harsher sanctions. It is even possible that we may bridge the chasm between the judging and the judged and, so, reestablish the consent that makes effective punishment possible.

But there are also some hints of a darker future on the horizon. ${ }^{101}$ And even if we never slip completely into the nightmare outlined above, it is surely true, even now, that some of the dehumanizing violence on both sides of the crime war stems from the debasement of retributivist rhetoric.

Moreover, the worst aspect of our predicament is that it leaves us frustrated and unhappy about whatever level of crime control we are able to achieve. It is possible to imagine a world where people would feel about crime the way they presently feel about earthquakes and floods. But our commitment to a freewill, retributivist ideology of criminal justice prevents us from attaining the peace that comes with acceptance of the inevitable. ${ }^{102}$ Instead, we feel angry at criminals, and we will continue to feel that anger as long as it is necessary to justify distributional outcomes. We cannot abandon our retributivist ideology, for to do so would be to forego the crime prevention function that blaming serves. Yet neither can we afford to act on our anger, for that course risks beginning a downward cycle of violence. Paralyzed by the contradictory deterrent and distributive functions of blaming, we are doomed to endure more crime than we think we deserve.

rights." Fairchild, Politicization of the Criminal Offender: Prisoner Perceptions of Crime and Politics, 15 Criminology 287, 294 (1977).

100. The Uniform Crime Report published by the Federal Bureau of Investigation shows a marked decrease in the number of offenses reported to law enforcement agencies in recent years. Federal Bureau of Investigation, Uniform Crime Report-1983 Preimimary Annual Release (Apr. 19, 1984); Federal. Bureau of Investigation, Crime Statistics-Crime in the United Stales-1982, FBI LAw ENForcement BuLL., Oct. 1983. It is not clear, however, that the data on the amount of crime, even if accurate, provide a useful measure of the social cost of crime. It is possible that a decline in crime is caused by adaptive, self-protective behavior that reduces the number of criminal episodes but nevertheless imposes real social costs on potential victims. See supra pp. 343-44 and note 87.

101. See, e.g., C. Silberman, Criminal. Violence, Criminal Justice 3-20, 60-65 (1978) (discussing fear and apprehension resulting from rise in violent and often vicious crimes).

102. Experimental data support the hypothesis that "[s]ubjects who attribute their inability to control an aversive outcome to their own inadequacy appear to experience considerably more stress than subjects who attribute it to factors in the environment or situation." Wortman, Panciera, Shusterman \& Hibscher, Attributions of Causality and Reactions to Uncontrollable Outcomes, $12 \mathrm{~J}$. Experimental Soc. Psychology 301, 311 (1976). 


\section{The Yale Law Journal}

Volume 94, Number 2, December 1984

\author{
Mark E. Haddad \\ Editor-in-Chief \\ Beth S. Brinkmann \\ Julia E. Guttman \\ Peter D. Keisler \\ Sarah Korn \\ Robert A. Long \\ Note Editors
}

Amy L. Henrich

Managing Editor

Lynn A. Baker

Anita Bernstein

Ronald D. Lee

Howard M. Shapiro

William M. Treanor

Article $\mathcal{F}^{\circ}$ Book Review Editors

Senior Editors

Pauline E. Calande

Sharon A. Hooper

Niki Kuckes

John R. Low-Beer
David A. Martland

Emily S. McMahon

John B. Sandage

Gene C. Schaerr

Paul Schwartz
Gene B. Sperling

Peter P. Swire

Stephen H. Willard

Wendy A. Wolf

\section{Editors}

Robert S. Adelson

Thomas P. Arden

David M. Aronowitz

Patrick A. Broderick

Kenneth Ghristman

Stephen M. Gutler

David R. Dow

Deborah D. Dupire

Peter R. Ezersky

Sarah B. Gordon

Rosemary Herbert

Alan Hirsch

Kenneth G. Johnsen

Howard Kruse

Ronald J. Kuerbitz

Christopher C. Magorian
David C. Marcus

Kathleen L. Roin Reva Siegel

A. Clayton Spencer

W. Danforth Townley

Stephen A. Warnke Jack Wenik Songyi Zhang

Business Manager: Pamela Standish

Editorial Assistant: Rosemary B. Carey

\section{Student Contributors to this Issue}

Beth S. Brinkmann, The Presumption of Life: A Starting Point for a Due Process Analysis of Capital Sentencing

Sarah Korn, Property Rights and Job Security: Workplace Solicitation by Nonemployee Union Organizers

Ronald D. Lee, Jurisdiction Over Foreign States for Acts of Their

Instrumentalities: A Model for Attributing Liability

Robert A. Long, Jr., A Theory of Hypothetical Contract 